\title{
En mann i 50-årene med hypotensjon og hyponatremi
}

\author{
Pasienten, en mann i 50-årene, ble innlagt akutt med brystsmerter, \\ hypotensjon og hyponatremi. Gjennom utredningen ble det påvist en \\ bakenforliggende tilstand utenom det vanlige.
}

Se kommentar side 2012 og kunnskapsprøve på www.tidsskriftet.no/quiz

\author{
Charlotte Gibbs \\ lottegibbs@gmail.com \\ Harald Bull Ragnum* \\ Olav Svindland \\ Medisinsk klinikk \\ Sykehuset Telemark, Skien \\ * Nåværende adresse: \\ Avdeling for strålingsbiologi \\ Institutt for kreftforskning \\ Oslo universitetssykehus, Radiumhospitalet
}

Mannen, som var i midten av 50-årene, ble innlagt via AMK på grunn av retrosternale brystsmerter som forverret seg ved bevegelse og respirasjon. Smertene hadde bygd seg opp i løpet av omtrent ti timer, og han beskrev også tiltakende smerter $i$ begge skuldre. Ambulansepersonellet hadde gitt ham $4 \mathrm{mg}$ morfin før ankomst til sykehuset, noe han var blitt påfallende sløv av.

Pasienten hadde hatt refluksplager i mange år og hadde fått behandling med protonpumpehemmer med god effekt. En måned før innleggelsen var han gastroskopert på grunn av nyoppståtte plager med kvalme og oppkast. Det ble påvist lett øsofagitt og moderat duodenitt.

I akuttmottaket var pasienten hypotensiv, med et blodtrykk på 98/55 mm Hg. Pulsen var regelmessig på 86, temperaturen var $37,6{ }^{\circ} \mathrm{C}$. Undersøkende lege journalførte at pasienten virket sløv. Han var gulgrå, men tørr og varm i huden, hadde god puls i begge lysker, og det var ingen åpenbare nevrologiske utfall. Den kliniske undersøkelsen var for øvrig uten anmerkninger. EKG viste sinusrytme med T-inversjoner $i \mathrm{V4}$-V6 og små utslag $i$ ekstremitetsavledningene, tolket som uspesifikke funn. Han hadde lett hypoksi med $\mathrm{pO}_{2}$ på $8,9 \mathrm{kPa}$, men normal $\mathrm{pH}$ og $\mathrm{pCO}_{2}$. Blodprøver viste lettgradig anemi, med $\mathrm{Hb} 11,7 \mathrm{~g} / 100 \mathrm{ml}(13,4-17,0 \mathrm{~g} / 100 \mathrm{ml})$, lett forhøyet CRP-nivå på $22 \mathrm{mg} / \mathrm{l}(<5 \mathrm{mg} / \mathrm{l})$, hyponatremi - $130 \mathrm{mmol} / \mathrm{l}(136-146 \mathrm{mmol} / \mathrm{l})$ - og lett økt d-dimer 0,8 (0,0-0,5). Ellers var orienterende blodprøver inklusive kreatinin og hjerteinfarktmarkører upåfallende.

Brystsmerter kan være forårsaket av sykdommer i hjertet, lunger, pleura, aorta, oesophagus/gastrointestinaltractus og muskel-skjelett-systemet. I tillegg kan de være psykogent betinget. Vår pasient hadde ved innleggelsen retrosternale brystsmerter, hypotensjon og lett hypoksi. Hjerteinfarkt, dissekerende aortaaneurisme, pneumoni og lungeembolisme ble ansett som de mest sannsynlige differensialdiagnosene.

Kort tid etter ankomsten til sykehuset falt blodtrykket til 70/28 $\mathrm{mm} \mathrm{Hg}$. Pasienten ble blek og kaldsvettet og anga at han hadde sterke smerter i epigastriet. Han ble flyttet til intensivavdelingen, og det ble startet behandling med væske og efedrin. Han fikk $5 \mathrm{mg}$ morfin mot smerter, men ble uvel av dette. Det ble videre ordinert $1 \mathrm{mg}$ ketobemidon ved behov. Man mistenkte nå vaskulær katastrofe $i$ thorax/abdomen eller gastrointestinal blødning/perforasjon, men hjerteinfarkt var foreløpig ikke utelukket.

Det ble utført akutt CT thorax/abdomen med spørsmål om dissekerende eller rumpert aortaaneurisme. Denne undersøkelsen viste upåfallende aorta, ellers var det normale funn i abdomen. Man fant imidlertid perikardvæske og sparsomme infiltrater basalt bilateralt $i$ lungene. Funnene i lungene var lite uttalte, og man valgte å la være å starte behandling mot mulig pneumoni. Undersøkelsen var ikke teknisk egnet til å bedømme om pasienten kunne ha lungeembolisme.

Vakthavende assistentlege utførte en orienterende ekkokardiografi, som viste god kontraktilitet i myokard og en væskebrem på $0,5 \mathrm{~cm}$, uten tegn til tamponade. Troponin I og CK-MB kontrollert seks timer etter innkomst var normale, og hjerteinfarkt kunne utelukkes. Hemoglobinnivåene var stabile ved gjentatte målinger, og det var ingen tegn til pågående gastrointestinal blødning. Tilstanden ble tolket som viral perikarditt, og pasienten ble observert $i$ intensivavdelingen. Han fikk ketobemidon ved behov mot smerter, ellers ingen behandling mot perikarditt. Det ble ikke gitt ikke-steroide antiinflammatoriske midler (NSAID) på grunn av nylig påviste duodenittforandringer.

Ved viral perikarditt er intense respirasjonsog stillingsavhengige brystsmerter vanlig. Man forventer ellers et fredelig forløp, med mindre det oppstår komplikasjoner i form av hjertetamponade eller arytmier. Noen av pasientens symptomer, som hypotensjon og hypoksi, kunne ikke forklares ut fra perikarditten. Han var i dårligere tilstand enn det perikarditt skulle tilsi.

Dagen etter innleggelsen hadde pasienten fortsatt brystsmerter. Han hadde fått $5 \mathrm{mg}$ ketobemidon og 3 l væske siden innkomsten. Han var trett, blek og pustet overfladisk. Temperaturen var $38,2^{\circ} \mathrm{C}$, blodtrykket 100/ $60 \mathrm{~mm} \mathrm{Hg}$ og blodgass uten $\mathrm{O}_{2}$-tilskudd viste fortsatt hypoksi, med $\mathrm{pO}_{2}$ på $8,0 \mathrm{kPa}$. Han hadde stigende infeksjonsmarkører, med leukocyttnivå 12,7 · 10\%/log CRP-nivå på 123 $\mathrm{mg} / \mathrm{l}$. Det ble tatt CT thorax med spørsmål om lungeembolisme. Det ble ikke funnet emboluser, men tiltakende fortetninger basalt $i$ lungene og økende mengde perikard-og pleuravæske sammenliknet med CT-undersøkelsen fra dagen før.

Ekkokardiografi utført av kardiolog viste en normalstor, ikke-hypertrof venstre ventrikkel med god kontraktilitet $i$ alle segmenter og ejeksjonsfraksjon over $55 \%$. Det ble påvist moderate mengder perikardvæske, med en væskebrem som nå var økt til 1,2-1,5 cm. Det var forsatt ingen tegn til tamponade, og perikardiocentese ble ikke foretatt.

Tilstanden ble nå tolket som en bakteriell pneumoni med affeksjon av pleura og perikard, eventuelt med tillegg av en viral eller immunologisk betinget perikarditt. Undersøkelser for pneumokokk- og legionellaantigen $i$ urin var negative. Under mistanke om utvikling av sepsis startet man opp intravenøs antibiotikabehandling med cefotaksim (tredjegenerasjons kefalosporin) $2 g \times 3$, supplert med erytromycin (makrolidantibiotikuml 500 mg × 4 for å dekke atypiske bakterier. I tillegg ble det startet behandling med prednisolon $60 \mathrm{mg} \times 1$ mot perikarditt.

Tre døgn etter innleggelsen var pasienten allment og respiratorisk bedre. Ekkokardiografi viste avtakende mengder pleura- og perikardvæske. Prednisolondosen ble redusert til $40 \mathrm{mg} \times 1$. Han hadde imidlertid vedvarende lett hyponatremi. Det kom frem at 


\begin{tabular}{|c|c|c|}
\hline \multicolumn{3}{|c|}{$\begin{array}{l}\text { Tabell } 1 \text { Blodprøver tatt i utredningen av } \\
\text { hyponatremi. Prøvene er tatt fastende kl } 0800\end{array}$} \\
\hline Serum & Verdi & $\begin{array}{l}\text { Referanse- } \\
\text { område }\end{array}$ \\
\hline $\mathrm{Na}(\mathrm{mmol} / \mathrm{l})$ & 131 & $137-145$ \\
\hline $\mathrm{K}(\mathrm{mmol} / \mathrm{l})$ & 4,2 & $3,6-5,0$ \\
\hline Osmolalitet (mosmol/kg) & 272 & $280-300$ \\
\hline Kortisol (nmol/l) & 173 & $180-750$ \\
\hline TSH (mIU/l) & 1,5 & $0,5-3,6$ \\
\hline Fritt T4 (pmol/l) & 4,8 & $11-23$ \\
\hline
\end{tabular}

han ved to anledninger den siste måneden hadde fått påvist hyponatremi hos sin fastlege. Ifølge pasienten var hyponatremien blitt tolket som mulig bivirkning av esomeprazol (protonpumpehemmer). Esomeprazol ble derfor seponert et par uker før innleggelsen, og pasienten ble satt på lanzoprazol.

Fire døgn etter innleggelsen var pasienten i klar bedring hva angår pneumonien. Han ble overflyttet til sengepost for videre utredning av hyponatremien. Det ble tatt blodprøver, som vist $i$ tabell 1. Han hadde morgenkortisol under nedre referansegrense og lavt nivå av fritt tyroksin (fritt T4) uten stigning av thyreoideastimulerende hormon (TSH). Prøvene bekreftet en hypoton hyponatremi med kaliumverdier innenfor normalområdet.

Ved en utvidet anamnese kom det frem at pasienten hadde merket avtakende kroppsbehåring i flere år. Han hadde også over lengre tid kjent seg svakere og mindre opplagt enn tidligere, med tretthet og dårlig søvnkvalitet. De siste månedene hadde han vært plaget av morgenhodepine med assosiert kvalme, oppkast, synsforstyrrelser og svimmelhet samt nedsatt libido og erektil dysfunksjon.

Med disse nye opplysningene ble det stilt spørsmål om pasienten kunne ha en hypofysesvikt. Ved mistanke om dette måler man kortisol, adrenokortikotropt hormon (ACTH), fritt tyroksin (fritt T4), thyreoideastimulerende hormon (TSH), prolaktin, testosteron/østradiol, luteiniserende hormon (LH), follikkelstimulerende hormon (FSH), seksualhormonbindende globulin (SHBG), veksthormon og insulinliknende vekstfaktor 1 (IGF-1). På grunn av døgnvariasjoner bør prøvetakingen utføres om morgenen (1). I figur 1 er det en oversikt over hypofysens akser.

I tabell 2 vises pasientens hormonprøver. Prøvene ble tatt om morgenen før inntak av medikamenter. Nivåene av kortisol, fritt T4 og testosteron var under nedre referanseområde, uten at det var forhøyede verdier av de korresponderende hypofysehormonene (henholdsvis ACTH, TSH og FSH/LH). I tillegg hadde pasienten lave verdier av IGF-1 og dermed svikt i den kortikotrope, tyrotrope, gonadotrope og somatotrope akse. Han hadde normale verdier av prolaktin.

For å undersøke den kortikotrope aksen ble det gjort en kort Synacthen-test, der man administrerer syntetisk fremstilt ACTH. Serum-kortisolnivået før testen var $77 \mathrm{nmol} / \mathrm{l} .30$ minutter etter injeksjon av 0,25 mg Synacthen intravenøst var serum-kortisolnivået steget til $287 \mathrm{nmol} / \mathrm{l}$, etter $60 \mathrm{mi}$ nutter var det $345 \mathrm{nmol} / \mathrm{l}$.

Ved normalt fungerende binyrer skal kortisolverdien stige til minst $550 \mathrm{nmol} / \mathrm{l}$ (2). Nedsatt respons bekrefter binyrebarksvikt, men skiller ikke mellom primær og sekun-

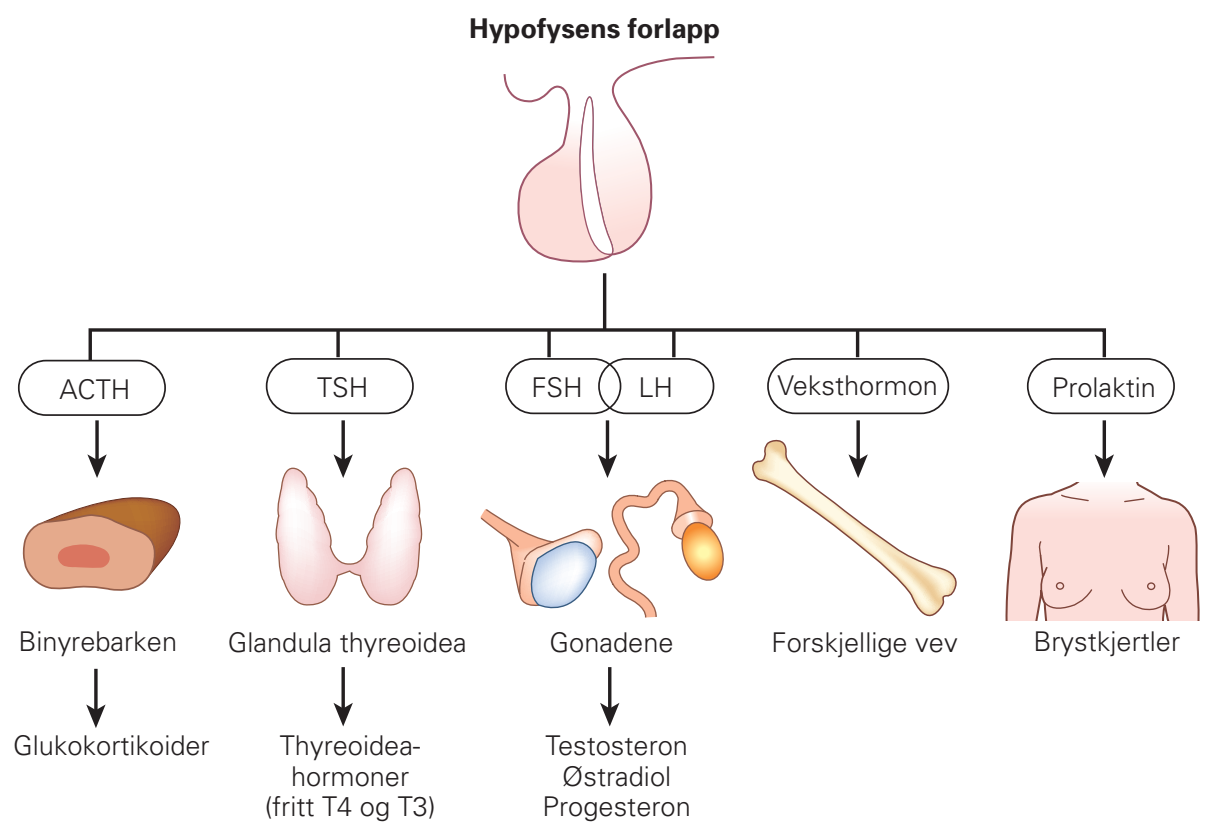

Figur 1 Skjematisk fremstilling av adenohypofysens akser

dær svikt. Vår pasient hadde manglende respons på testen. Det skyldes atrofi av binyrenes zona fasciculata på grunn av manglende ACTH-stimulering over tid, altså sekundær binyrebarksvikt. Han hadde fått behandling med prednisolon $i$ en uke før testen, noe vi mener er for kort tid til å kunne forklare den manglende responsen.

Det ble tatt MR av hypofysen, som viste et makroadenom som vokste gjennom sella turcica opp til chiasma opticum og trykte på denne. I koronalplanet var største diameter av tumoren $25 \mathrm{~mm}$, $i$ sagittalplanet største diameter $28 \mathrm{~mm}$ (fig 2).

Pasienten ble på bakgrunn av dette henvist til perimetriundersøkelse hos øyelege for å finne ut om tumoren påvirket synsfeltet. Dette var viktig med tanke på operasjonsindikasjonen og på hvor raskt han burde opereres. Perimetriundersøkelsen viste et lite synsfeltsutfall bitemporalt, mest uttalt på venstre øye.

Man kunne således konkludere med at pasienten hadde et hormonelt inaktivt hypofysært makroadenom og svikt i adenohypofysen og synsfeltsutfall. Hypofysetumorer opereres først etter at pasienten er stabilisert hormonelt, med mindre det er snakk om øyeblikkelig hjelp. Vår pasient ble satt på substitusjonsbehandling med kortison og tyroksin. Det er viktig à starte med kortison før tyroksin, siden tyroksin øker steroidbehovet og kan utløse en Addison-krise. Han ble henvist til operasjon og i mellomtiden utskrevet til hjemmet.

Ved utskrivningen var han i god allmenntilstand og uten smerter. Røntgen thorax viste klare lunger og nærmest fullstendig tilbakegang av pleuravæske bilateralt. Ekkokardiografi noen dager etter utskrivningen viste normale forhold.

En måned senere ble pasienten operert med endoskopisk, transsfenoidal reseksjon av hypofysetumoren - med ukomplisert forløp. Han var da stabilisert hormonelt med tyroksin og kortison, og man ønsket ikke å utsette operasjonen lenger på grunn av synsfeltsutfall. Ved tre måneders postoperativ kontroll ble det påvist svikt i samtlige akser $i$ adenohypofysen, og behandlingen ble supplert med veksthormon og testosteron. Neste kontroll er planlagt til 12 måneder postoperativt. Denne pasienten hadde en relativt stor resttumor, og det kan være aktuelt med reoperasjon eller bestråling av hypofysen. Han følges med MR-kontroll av hypofysen, undersøkelse av synsfelt og endokrinologisk vurdering. Ti måneder postoperativt uttalte pasienten at han følte seg i bedre form enn på lenge. Livsgnisten var kommet tilbake.

\section{Diskusjon}

Hypofysesvikt skyldes som regel hypofyseadenomer. Ved en ekspansiv prosess i hypofyseregionen vil hormonene typisk falle ut $\mathrm{i}$ en bestemt rekkefølge, først med svikt i den somatotrope akse. Deretter vil man kunne se 
Tabell 2 Blodprøver tatt i forbindelse med utredning for hypofysesvikt

\begin{tabular}{|lcc|}
\hline & Verdi & $\begin{array}{c}\text { Referanse- } \\
\text { område }\end{array}$ \\
\hline Kortikotrope akse & & \\
\hline ACTH (pmol/l) & 2,2 & $<10,2$ \\
\hline Kortisol (nmol/l) & 87 & $180-750$ \\
\hline Tyrotrope akse & & \\
\hline TSH (m/U/l) & 1,7 & $0,5-3,6$ \\
\hline Fritt T4 (pmol/l) & 6,6 & $11-23$ \\
\hline Gonadotrope akse & & \\
\hline FSH (IU/l) & 3 & $0-12$ \\
\hline LH (IU/l) & 1 & $0-12$ \\
\hline Testosteron (nmol/l) & 2 & $8-35$ \\
\hline Somatotrope akse & & \\
\hline IGF-1 (nmol/l) & 5,6 & $11-40$ \\
\hline Laktotrope akse & & \\
\hline Prolaktin (mIU/l) & 221 & $50-700$ \\
\hline
\end{tabular}

avtakende produksjon av hypofysehormonene i følgende rekkefølge: gonadotropiner (LH, FSH), ACTH, TSH og prolaktin. Unntakene er imidlertid mange. Symptomer og kliniske manifestasjoner er nær knyttet til hvilken konstellasjon av hormonsvikt som dominerer og hvor fort hypofysesvikten utvikles. Vanligvis utvikler denne seg over mange år, og det er ikke uvanlig med langtkommen svikt på diagnosetidspunktet. Ofte er det da en interkurrent sykdom som fører til en Addison-krise, hos vår pasient en pneumoni (3). Ved en Addison-krise er pasienten typisk mye sykere enn det den utløsende tilstanden skulle tilsi (4).

Addison-krise er en sjelden, men livstruende tilstand som skyldes akutt binyrebarksvikt. Utfordringen ligger i å oppdage tilstanden hos kritisk syke. Akutt binyrebarksvikt bør mistenkes hos pasienter med uforklarlig hypotensjon, gjerne i kombinasjon med hyponatremi, og ved sepsis og sirkulasjonssjokk som ikke responderer adekvat på behandling. Tilstanden krever umiddelbar behandling med fysiologisk saltvann og hydrokortison intravenøst (4). Pasienten vår fikk på et vis behandling mot Addisonkrisen før den ble oppdaget, i og med at man ga prednisolon mot perikarditt.

Hypokortisolisme kan være forårsaket av primær binyrebarksvikt med manglende re- spons på ACTH eller sekundær binyrebarksvikt med nedsatt sekresjon av ACTH fra hypofysen. Ved primær binyrebarksvikt er produksjonen av aldosteron nedsatt, noe som kan gi uttalt hyponatremi, hyperkalemi og hypovolemi. Siden aldosteronproduksjonen er bevart ved sekundær binyrebarksvikt, er hyponatremien mindre uttalt, og kaliumnivået forblir normalt. Det sistnevnte var tilfellet hos vår pasient.

Pasientens hyponatremi kan skyldes både hypotyreose og hypokortisolisme. Begge tilstandene kan gi økt ADH-sekresjon, som fører til vannretensjon og hyponatremi. Hyponatremi er en kjent, men sjelden bivirkning av protonpumpehemmere, men hos vår pasient skyldes hyponatremien hypofysesvikt.

Sentralt i den presenterte sykehistorien er funn av perikard- og pleuravæske. Dette kan ses hos pasienter med moderat til alvorlig hypotyreose. Hypotyreosen hos vår pasient var nok ikke så uttalt at den burde ha gitt pleura- og perikardvæske. Han kan imidlertid ha hatt pleuritt og perikarditt sekundært til en pneumoni.

Ved innkomst var pasienten anemisk. Dette kan ses ved mangel på kortisol, tyroksin og androgener, da disse hormonene påvirker erytropoesen. Vår pasient hadde en gulaktig hudfarge. Dette kan ses ved langvarig hypotyreose og skyldes opphopning av karoten i huden (5).

Pasienten vår ble påfallende sløvet av morfin. Personer med hypotyreose og binyrebarksvikt kan ha økt følsomhet for opioider (6), som derfor bør brukes med forsiktighet av denne gruppen.

En lærdom fra denne kasuistikken er at pasienter med uforklarlig hyponatremi bør utredes for hypotyreose og binyrebarksvikt. Hypofysesvikt utvikler seg vanligvis over flere år, og det er ikke uvanlig med langtkommen svikt på diagnosetidspunktet. Ofte er det da en interkurrent sykdom som fører til en Addison-krise.

Pasienten har gitt samtykke til at artikkelen blir publisert.

Oppgitte interessekonflikter: Ingen

\section{Charlotte Gibbs (1975)}

er konstituert overlege ved endokrinologisk avdeling.

Ingen oppgitte interessekonflikter.

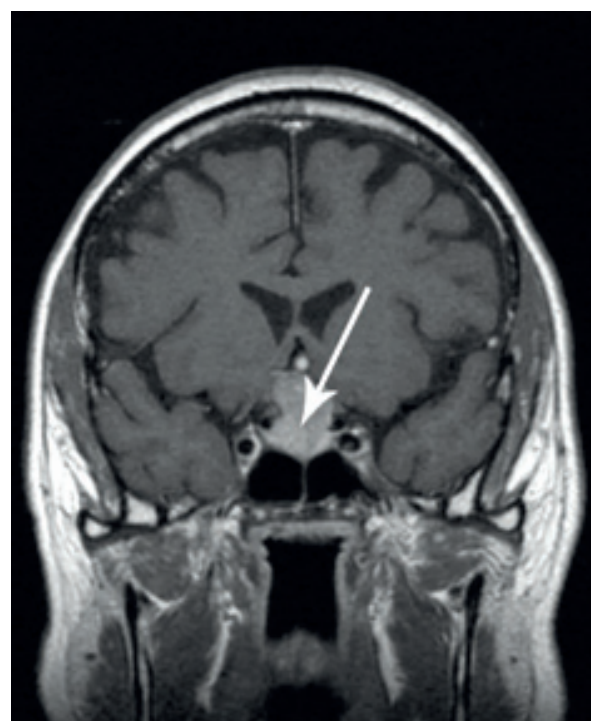

Figur 2 MR-undersøkelse av hypofysen viser et makroadenom (pil) som vokser gjennom sella turcica opp til chiasma opticum og trykker på denne

\section{Harald Bull Ragnum (f. 1985)}

er lege og stipendiat ved Avdeling for strålingsbiologi ved Institutt for kreftforskning på

Radiumhospitalet.

Ingen oppgitte interessekonflikter.

\section{Olav Svindland (f. 1946)}

er spesialist i endokrinologi og i indremedisin. Han er overlege ved endokrinologisk seksjon, Sykehuset Telemark.

Ingen oppgitte interessekonflikter.

\section{Litteratur}

1. van Aken MO, Lamberts SW. Diagnosis and treatment of hypopituitarism: an update. Pituitary 2005; 8: 183-91.

2. Universitetssykehuset Nord-Norge. Synacthenhurtigtest. www.unn.no (25.4.2010)

3. Lund-Johansen M, Aanderud S, Schreiner T et al. Ikke-hormonproduserende hypofyseadenomer. Tidsskr Nor Lægeforen 2003; 123: 2253-6.

4. Husebye ES. Akutt binyrebarksvikt - symptomer og behandling. Tidsskr Nor Lægeforen 2001; 121 1260

5. Husebye ES. Endokrinologisk akuttmedisin. Tidsskr Nor Legeforen 2008. 128. 574.

6. Hallengren B, Karlsson A. Sköldkörteln - tyreodiea. I: Werner S, red. Endokrinologi. Stockholm: Liber Forlag, 2007: 117

Manuskriptet ble mottatt 7.1. 2010 og godkjent 27.5. 2010. Medisinsk redaktør Lars Frich. 